信濃川長岡地区の低水路河道計画と対策工の勃果について

The planning of main channel and effect of its measures in the Nagaoka area of Shinano River

$\begin{array}{lllll}\text { 建設省信濃川工事事務所 } & \text { 斎藤 } & \text { 正勝 } & \text { M. S a i t o } \\ \text { 建設省信濃川工事事務所 } & \text { 岸田 } & \text { 弘之 } & \text { H. K i s h i d a } \\ \text { 建設省信濃川工事事務所 } & \text { 南雲 } & \text { 克彦 } & \text { K. N N g g u mo }\end{array}$

1. 㹥じかに

信濃川は、流域面積 $11,900 \mathrm{~km}$ 、流路延長 $367 \mathrm{~km}$ の我が国有数の大河である。

信濃川の大河津分水路上流 $15.5 \mathrm{~km}$ より $22.5 \mathrm{~km}$ までの区間は長岡市の中央を貫流しており、信濃川沿川でも 最も重要な区間である。この地区は山間部を流下した信濃川が平野部に出た所で、雪国特有の持続時間の長 い融雪出水が生じ、河床勾配も急変する地区でもある。

このため、河状恃著しく荒廃し、乱流が激しく、各所に水衝部が存在し、河川構造物の損傷も著しく、治 水上の危険性も增大してきたため、これらに対処する低水路の整備を基本とした河道計画が樹てられた。

計画の施工方法、工法、施工順序については、模型実験により検討されたもので、昭和50年頃から本格的 工事に着手され、10年を経過し、その勃果も着害に現れてきている。

本稿では、対策工の変遷（勃果）、河床の変動について、現地観測を行い、模型実験と対比して考察した ので報告する。

2. 模型実験と低水路河道計画

(1) 河道計画の基本方針

長岡地区河道計画区間は図一 1 に示すように、

長岡市を中心に $15.25 \sim 22.25 \mathrm{~km}$ の区間である。

この区間の基本方針㹥以下のようである。

1)，堤防法線は現状のままとする。

2). 蛇曲の著しい現低水路を整正するため、複 断面とし新低水路を造成して、危険な水衝部 の解消と高水敷の高度利用を図る。

3). 低水路の疏通能力は、 $2 \sim 3$ 年に一度の生 起流量程度とし、過去 40 年間の小千谷観测所 の流量記録から低水路流量は $4,000 \mathrm{~m}^{3} / \mathrm{s}$ とす る。

4). 計画河床の絴断形は河道計画区間が 15.25

〜22.25 km と部分的なため、全川としてのバ ランスを考虑してできるだけ現況河道に合わ せることとし、図ー 2 に示すように河床勾配 $1 / 670 \sim 1 / 1,600$ を 段階に変化させる。

5). 低水路川幅は、現況河道の低水路の平均値 である $320 \mathrm{~m}$ を採用する。流下能力の検討から 低水路深は下流で約 $5 \mathrm{~m}$ 、上流で $4.5 \mathrm{~m}$ となる。

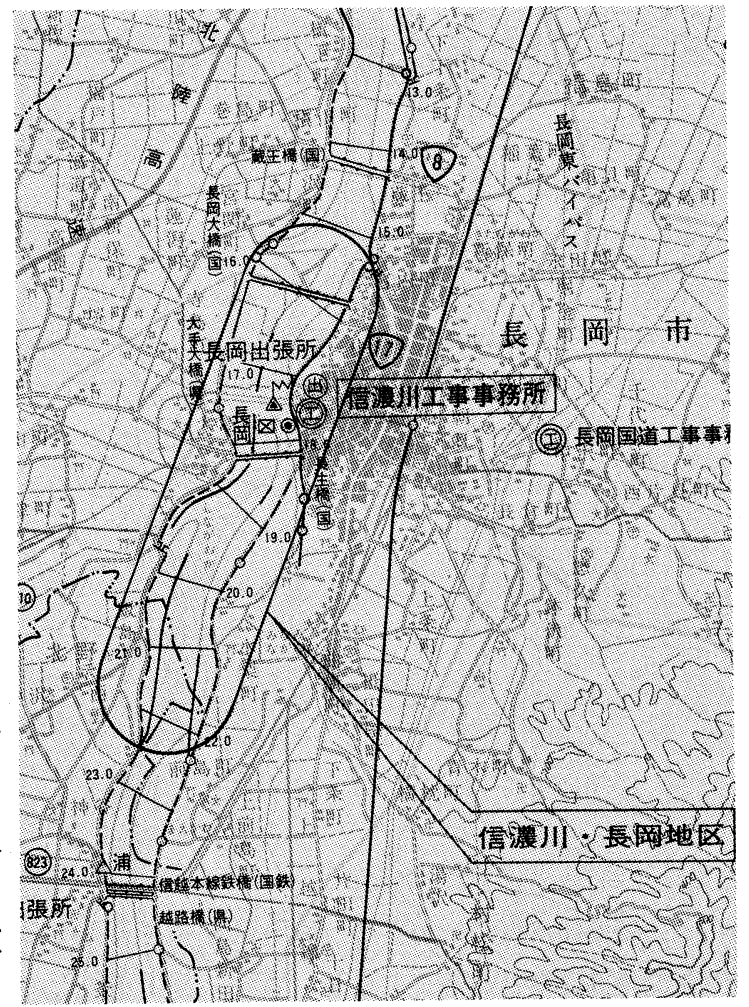

図-1，長岡地区河道計画位置図 
6). 低水路法線は現況河川の流心線の経年変化 を参考として、現在の河状にあった低水路法 線を一次案とし、これをもとに模型害験を行 って修正を加えながら最良案を決定する。

（2）低水路河道法線の検討

1の6)で述べたように低水路法線について図一 $3 \sim 6$ のような検討経過を経て最終法線が決定さ れている。

1). 最媣河床位置の変遷（図－3）から、最近 の10年間ではその主流路の位置は殆んど変化 していない。水衝部である $18 \mathrm{~km}$ 付近の右岸の 流路も固定されており、ここては低水路を可 能な限り河道中央に移動させることとして流 心線をもとに一次案が決定された。

2). 新低水路の河道の安定性を調べるために移

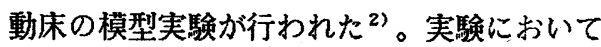
は図一 4 に示すように長時間通水と不定流実 験が行われたが $21 \mathrm{~km}$ 付近の水衝部の移動、高 水敖にのりあげる流速等の問題があり、低水 路河道の設定が必ずしも淦足する状況にない ことから図ー 5 のような検討を経て最終案が 設定されている。この案は低水路を $400 \mathrm{~m}$ 拡 大したことと、 $21 \mathrm{~km}$ 付近右岸の水衝部を固定 する目的で法線形状を可能な限り湾曲させた ものである。

3). 最終案については、(1)低水路内の流れがス ムースになり、高水敷の荒廃は著しく軽減さ れたことと、長時間通水 $\left(4,000 \mathrm{~m}^{3} / \mathrm{s}\right)$ におい て水衝部におけるBar の移動があまりないこ とが認められた。最終案と昭和48年の河道を 比較すると図一 6 のようであり、当時の水衝 部を締奶って高水敷の造成を行うことにな る。このため、施工隻岸による整備、低水 路の掘削、導流水制による自然堆積を利用し て実施することになり、その構造や施工順序 についても模型実験によって検討された

（3）対策工の施工の順序

低水路河道については、種々の検討を加え決定されたが、実際に、対策工を施工する場合、現況河道 の特性が非常に複雑なため、慎重な施工が望まれる。

一方、水衝部の解消は、早急に行われる必要があるが、この箇所は蛇行現象が支配的な所であるため、 
対策工の施工の影響でこの箇所の条件を変えることにより、蛇行ピッチの変化により上下流に影響を与 えることも考えられる。

従って、施工に際しては、施工による影響を予測し、その保護を行ってから水衝部の施工を行うとい う方法をとる必要がある。

施工順序の検討にあたっては、

(1) 水衝部の位置と範囲

(2) 水衝部施工後の影響

(3) 水衝部の施工法

の点の解明に目的をおいて、図一7のように区間全体の施工順序をまとめた。

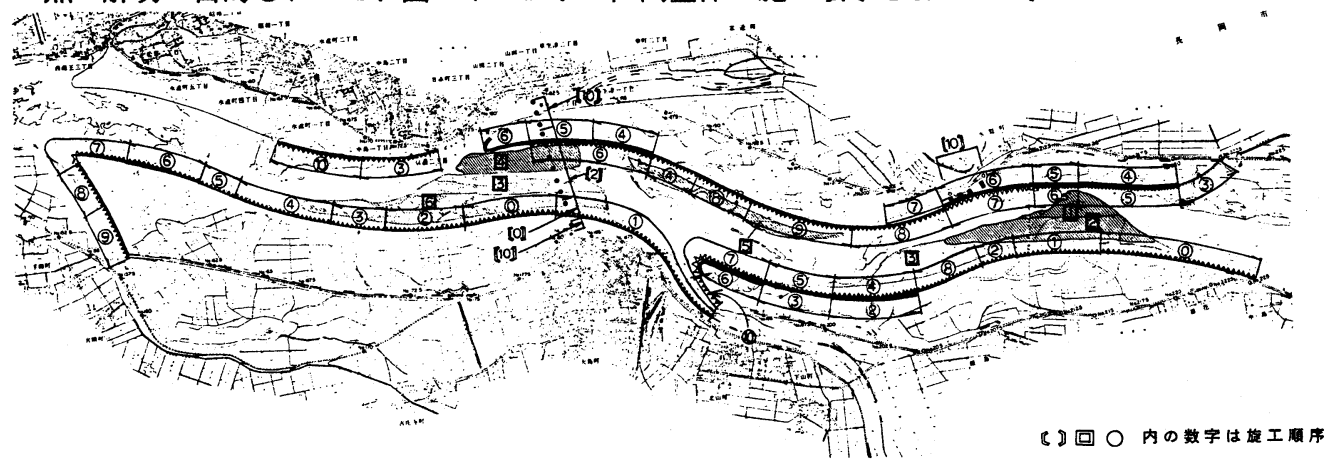

図-7. 河道計画施工順序检討結果

\section{3. 対策工の実施}

本格的工事は昭和50年頃から実施しており、 施工の変遷と施工位置を図一 9 に示した。

現在までの整備率は図ー8に示しており、 全体として約 $60 \%$ の進捗となっている。

\begin{tabular}{|c|c|c|c|c|c|c|c|c|c|}
\hline \multirow{2}{*}{ 地 区 } & \multirow{2}{*}{ 和 } & \multirow{2}{*}{ 全体栖 } & \multirow{2}{*}{ 完成 } & \multicolumn{6}{|c|}{ 谁持 } \\
\hline & & & & 20 & 40 & 6 & & 80 & 100 \\
\hline \multirow{3}{*}{ A地区 } & 速波嚗 & $2.3 \mathrm{~km}$ & $1.322 \mathrm{am}$ & 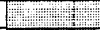 & 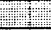 & & & & \\
\hline & 常 & $1.9 \mathrm{~km}$ & $0.5 \mathrm{~km}$ & - & $!$ & & & & \\
\hline & 制 & 8 巷 & 8 粂 & 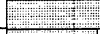 & 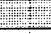 & 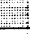 & & +4 & +3 \\
\hline \multirow{2}{*}{ B地区 } & 来溹堤 & $0.7 \mathrm{~km}$ & $0.19 \mathrm{a}$ & 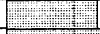 & 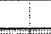 & & & & \\
\hline & 崖 & $2.5 \mathrm{~km}$ & $2.5 \mathrm{~km}$ & 5 & $=1$ & & & 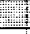 & 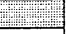 \\
\hline C地区 & 岸 & $2.5 \mathrm{~km}$ & $0.62 \mathrm{a}$ & 7 & 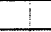 & & & & \\
\hline D地区 & 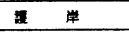 & $4.2 \mathrm{ka}$ & $2.78 \mathrm{~kat}$ & $\sqrt{14}$ & 3 & 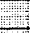 & & & \\
\hline \multicolumn{2}{|c|}{ 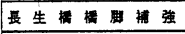 } & 8 基 & $8 \%$ & 3 & +1 & 7 & $=$ & & 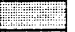 \\
\hline \multicolumn{2}{|c|}{ 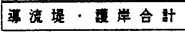 } & $14.1 \mathrm{~km}$ & $7.91 \mathrm{~km}$ & - & 1 & 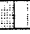 & & & \\
\hline
\end{tabular}

図一 8 . 事業進捗状況表（昭和60年度）

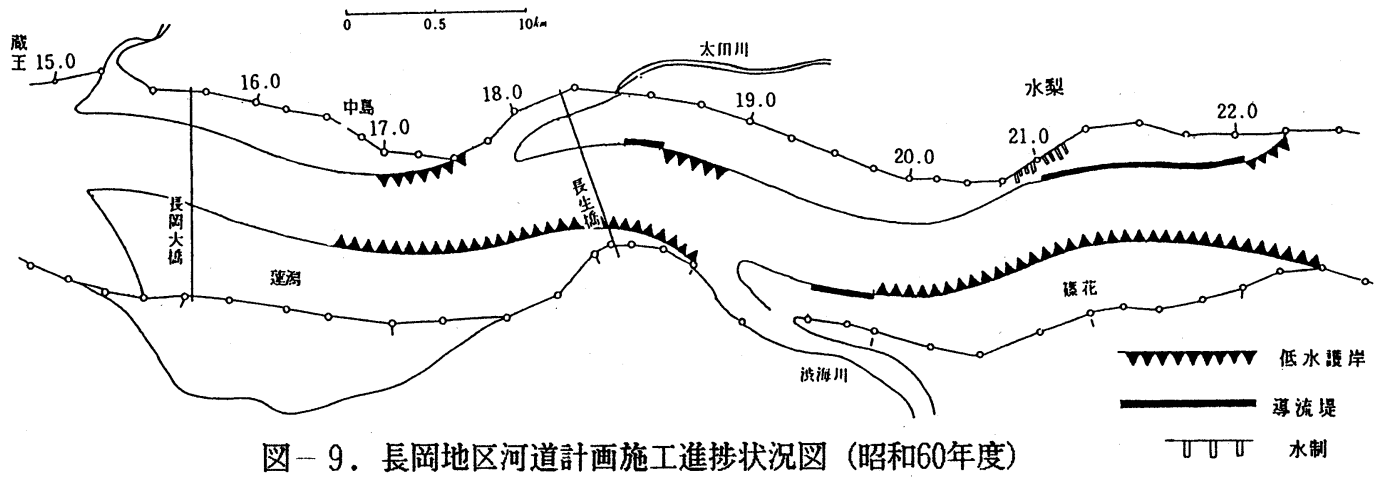

4. 現地観测による検討

（1）水文特性

長岡地区河道形成に支配的役割を果たす河道の主な流況㹥表一 1 の通りであり、図-10に示すように 年総量の大きな変化はみられないが、主要高水のピーク流量の発生状況を見ると、昭和56年以降 $(59$ 年は 融雪洪水）に $4,000 \mathrm{~m}^{3} / \mathrm{s}$ 以上の大洪水が連続して発生している。 


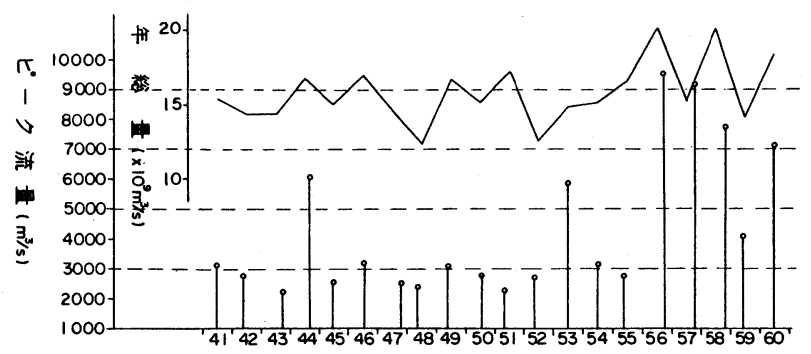

表-1. 小千谷地点の平均流況

図-10.小千谷地点流量経年変化

(2) 河道の変遷

図-11には、河道計画区間の本格的工事の着手前と近年の河床変化、また、写真 1 はこの区間の航空 写真である。

1). 低水路平均河床高は $15.5 \mathrm{~km} 、 20.0 \mathrm{~km}$ 下流を除いては1 2m低下傾向にある。

2). 最深河床高は、上流区間を除いては昭和55年までは大きな変化は見られないが、近年局所洗掘が增 加している。

3). 水衝部の本格的施工の伴い、低水路河道が固定されつつあり、その中で主流線が支配されてきてい る。これは写真 1でも見られるように、低水路内での砂础堆（単列蛇行）の発達が著しいことからも 言える。

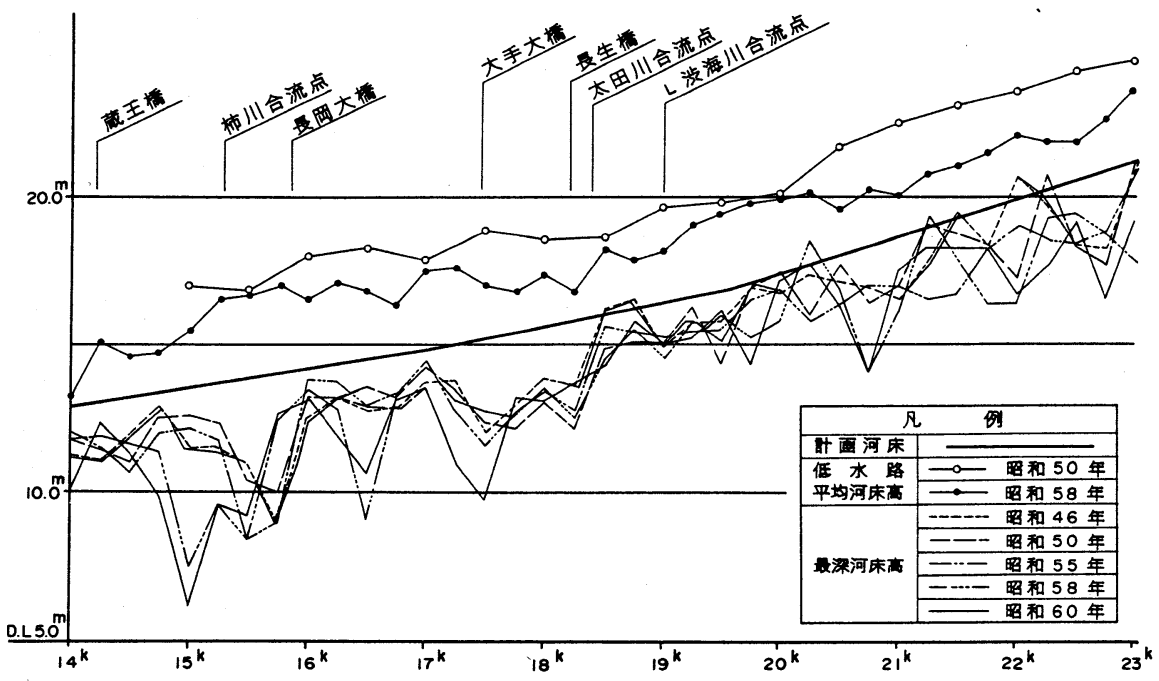

図-11. 河床変動経年変化図

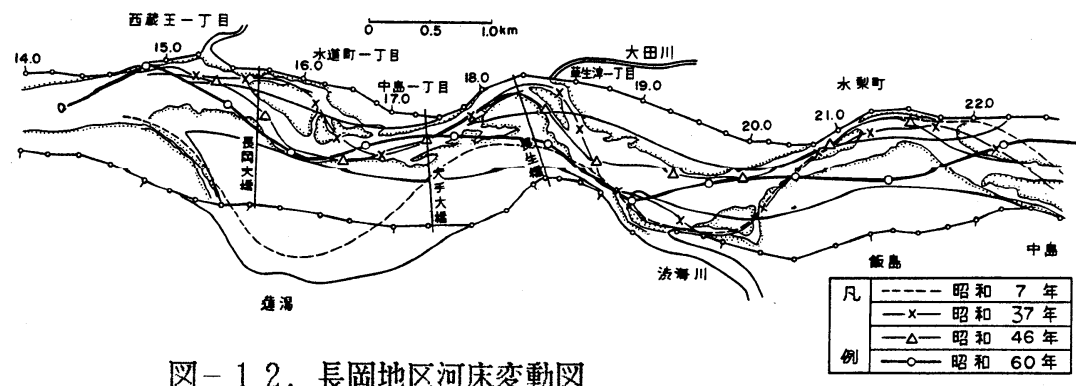

図-12, 長岡地区河床変動図 


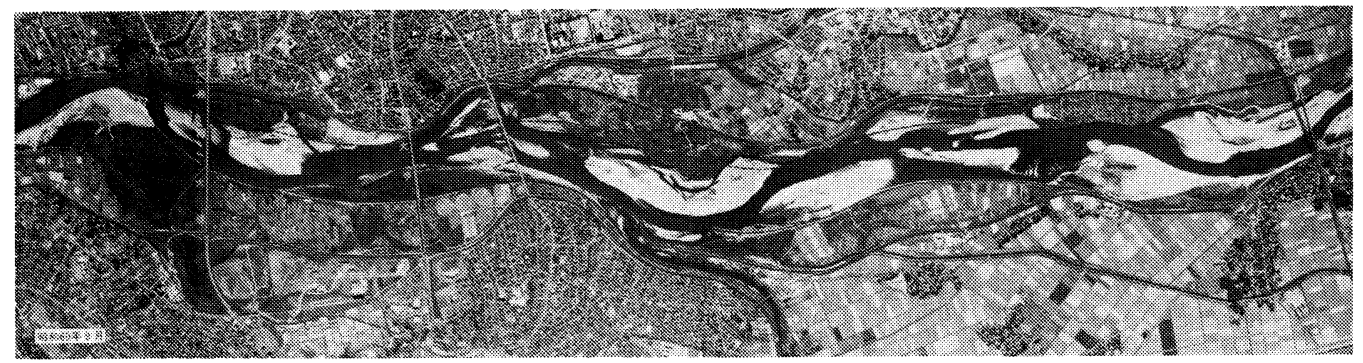

写真 -1 長岡地区航空写真（昭和60年10月撮影）

(3) 対策工の効果

長岡地区河道計画の主要対策工は、(1)導流堤、(2)低水路護岸、(3)低水路掘削であり、この他改修等の影 響を考虑して、橋梁の根継ざ等が先行して寒施されている。

低水路護岸は導流堤工事に対応して先行着手され、導流堤の影響による河岸侵食防止の効果を発揮して いる。掘削工事は、導流堤・護岸の諸工事に対応して必要な程度実施されている。各所の低水路工事は各 各その役割はあるが、主体的対処は導流堤工事であるので、その代表箇所として水梨地区導流堤（右岸21 〜22.5km)を取り上げ、その勃果について述べる。

(1) 昭和51年度の工事により、水梨地区右岸派流が遮断されて以来 $60 \%$ の進捗率となっている。

(2) 昭和56年までは直上流の河道が典型的な複列砂州の河床形態を示し、本地区に流入する主流路も河 道中央から流入している。しかし、昭和57年には約 $2 \mathrm{~km}$ 上流の越路橋付近の砂䃯堆の発達とあいまっ て、この地区でも右岸を凸とする大きな砂䃯堆が発達し、昭和58年には水梨導流堤の前面に砂䃯堆が 発達してきた。

(3) 写真一 $2 、 3$ で比較するように導流堤の背後には土仯が堆積し、昭和60年には本地区の水衝部は解 消されており、図-14に示すように 2〜4 m の堆積がある。

(4) 一方、導流堤前面の砂堆の発達により、主流路が左岸低水護岸に沿って流れ、局所洗掘を惹起し、 昭和59年には、低水護岸の欠壊を招いている。そのため、昭和59年に低水路中央部の仯堆の掘削を実 施している。

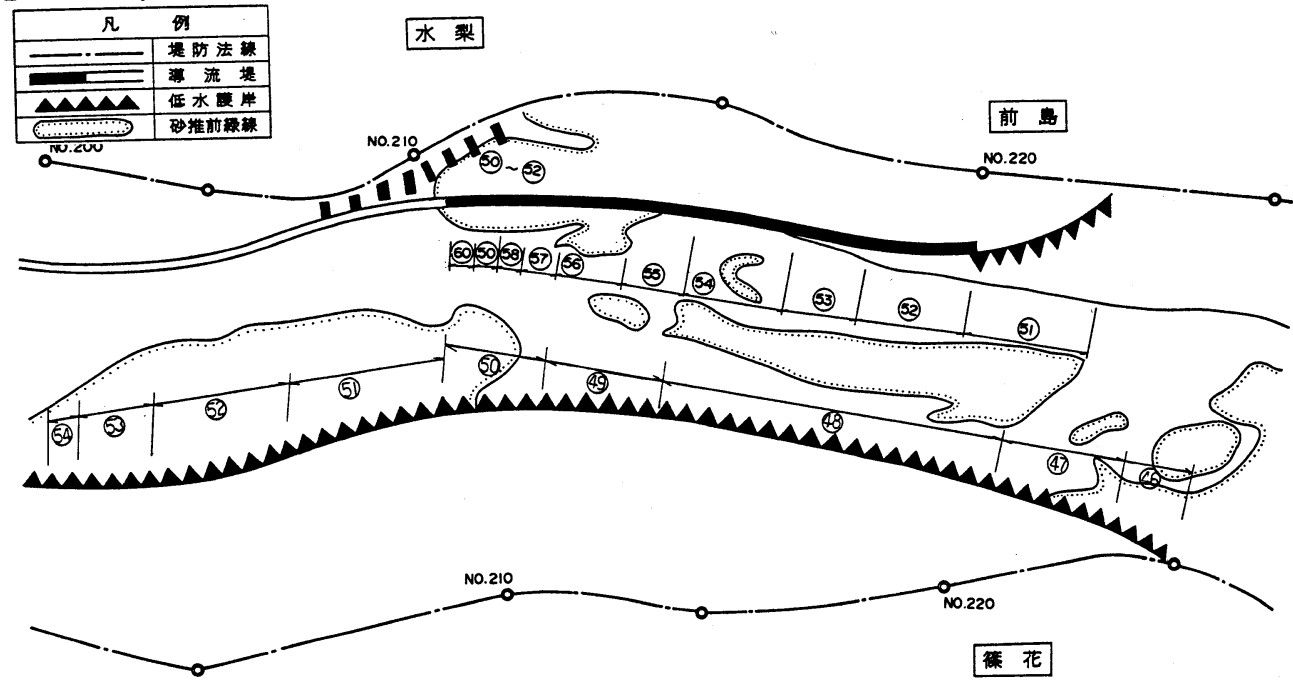

捚

図-13，水梨地区対策工施工状況図 

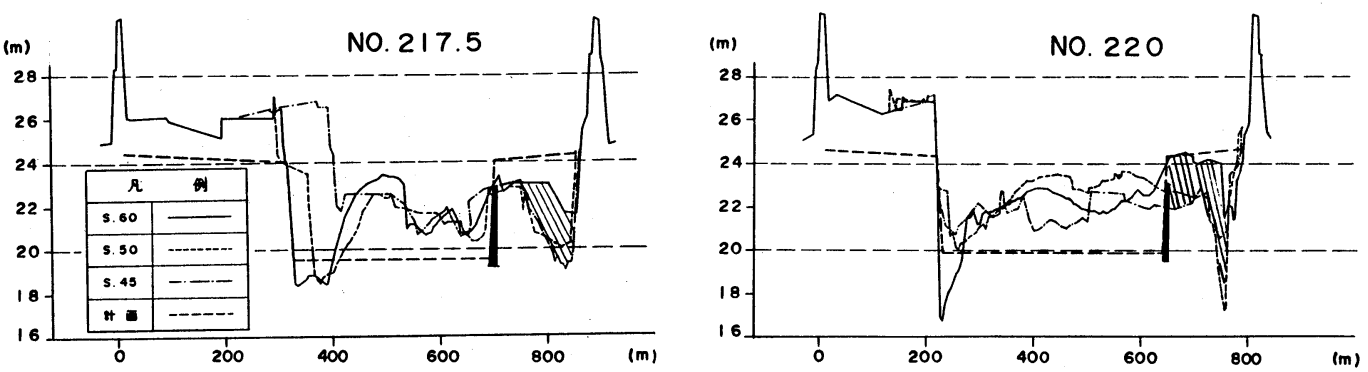

図-14.水梨 (導流堤) 付近経年横断変化図 導流堤による堆砂)

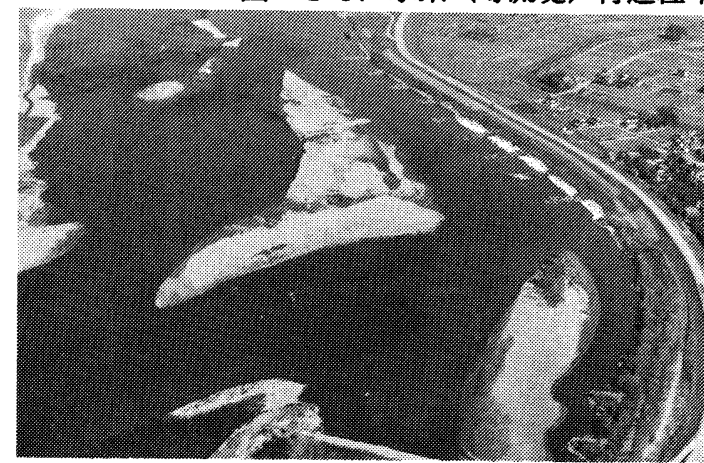

写真 $-2 （$ 昭和 52 年10月撮影）

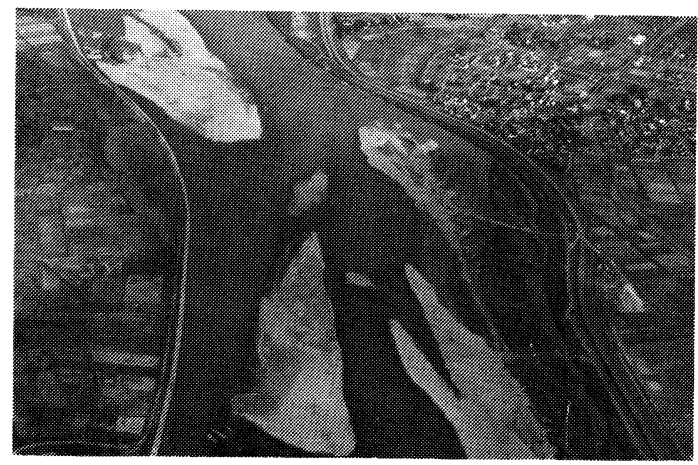

写真 -3 (昭和60年11月撮影)

\section{4. 模型実験との比較}

現地においては、模型実験により決定された低水路法線に従い、また、施工順序についても、相対的に大 きな違いのない形で進められており、現在までの対策工の進捗状況は、約 $60 \%$ である。

さらに、昭和56年には既往最大、59年に融雪最大を含み、56年から大洪水が連続して発生している。 このような状況の下で模型実験と現地の状況を比較してみると、

(1) 導流堤の進捗に伴い、その効果は着実に現れ、概ね模型実験の通りの結果となっている。

(2) 近年の大出水の発生之、本区間上流の河道計画の進捗に伴い、低水路の単列砂䃯堆化が著しい。この結 果、水梨上流での主流線が模型実験と異なっている。

\section{5. おわりに}

本研究では、長岡地区低水路河道計画の進捗に伴う河道の変遷と対策工の勃果について述べた。

信濃川のように、毎年確実に融雪出水による低水路満杯程度の流量が発生し、かつ、土砂の流送が多い河 川では、ここでとられた対策工が勃果的であることが明らかになった。

自然の動きは、実に複雑であり、我々が、その動きを把握し、予測し得る部分は極めて限られた範囲であ る。従って、計画の実施にあたっては、実施しつつその影響、効果を観察し、それを計画にフィードバック させながら進めて行く必要があることを充分認識して、今後とも低水路河道の安定を図って行きたいと考え ている。

\section{参考文献}

1) 吉川 秀夫編 : 流砂の水理学, 丸善 昭和60年

2）信襄川長岡地区河川計画模型実験報告書 その 1 ：土木研究所資料 第 786号，昭和47年

3 ）信濃川長岡地区河川計画模型実験報告書 その 2 ：土木研究所資料 第 904号，昭和49年

4) 建設省河川局治水課： 蛇行現象と河道計画，昭和57年 